\title{
EFEKTIVITAS LAYANAN PENGUASAAN KONTEN DENGAN TEKNIK LEARNING CELL UNTUK MENINGKATKAN MOTIVASI BELAJAR
}

\author{
Uswatun Khasanah \\ Prodi Bimbingan dan Konsling, FIP Universitas PGRI Semarang \\ e-mail ; uswatunkhasanah@gmail.com
}

\begin{abstract}
Abstrak
Penelitian ini dilatarbelakangi oleh kurangnya informasi siswa tentang cara belajar efektif dan efisien, cara mempersiapkan diri dalam menghadapi tes atau ujian, dan tentang kesulitan dalam menumbuhkan semangat belajar yang menurun. Metode penelitian yang digunakan adalah true eksperimental dengan pretest-posttest control group design. Populasi dalam penelitian ini adalah siswa kelas VIII pada semester $1 \mathrm{di}$ SMP Mardisiswa 2 Semarang, yang terdiri dari 5 kelas dengan jumlah 153 siswa, satu kelas digunakan untuk try-out, sedangkan sampelnya terdiri dari satu kelas yang digunakan sebagai sampel penelitian. Jumlah keseluruhan sampel adalah 123 siswa. Teknik sampling yang digunakan adalah teknik cluster random sampling. Nilai motivasi belajar diperoleh dari nilai pre-test dan post-test. Analisis yang digunakan untuk menguji validitas adalah korelasi product moment dan reliabilitas menggunakan rumus alpha. Hasil analisis uji t menunjukkan bahwa "Layanan Informasi dengan Teknik Learning Cell Efektif untuk Meningkatkan Motivasi Belajar Siswa Kelas VIII di SMP Mardisiswa 2 Semarang." Maka dapat disimpulkan penerapan layanan informasi dengan teknik learning cell efektif untuk meningkatkan motivasi belajar siswa kelas VIII di SMP Mardisiswa 2 Semarang.. Saran yang dapat peneliti sampaikan hendaknya guru pembimbing di sekolah memberikan layanan lanjutan berkenaan dengan motivasi dalam belajar.
\end{abstract}

Kata-kata kunci : Layanan Informasi dengan Teknik Learning Cell, Motivasi Belajar

\begin{abstract}
This research is motivated by the lack of student information about effective and efficient learning, how to prepare for tests or examinations, and about difficulties in fostering a decreased learning spirit. The research method used is true experimental with pretestposttest control group design. The population in this study were students of class VIII in semester 1 at SMP Mardisiswa 2 Semarang, which consisted of 5 classes with a total of 153 students, one class was used for try-outs, while the sample consisted of one class used as a research sample. The total number of samples was 123 students. The sampling technique used was cluster random sampling technique. The value of learning motivation is obtained from the pre-test and post-test scores. The analysis used to test validity is the product moment correlation and reliability using the alpha formula. $T$ test analysis results show that "Information Services with Effective Cell Learning Techniques to Increase Learning Motivation of Class VIII Students in Mardisiswa 2 Junior High School in Semarang." it can be concluded that the application of information services with effective cell learning techniques to improve student motivation in class VIII at Mardisiswa 2 Junior High School in Semarang. Suggestions that researchers can convey should guide teachers in schools provide further services regarding motivation in learning.
\end{abstract}

Keywords: Information Services with Cell Learning Techniques, Learning Motivation.. 


\section{Pendahuluan}

Pada era globalisasi seperti saat ini, pendidikan merupakan merupakan hal yang sangat penting dalam menyiapkan generasi yang cerdas, berdaya saing tinggi serta membentuk kepribadian suatu masyarakat. Sekolah merupakan salahsatu lembaga pendidikan formal yang secara tersistematis menyiapkan generasi bangsa ini untuk menghadapi berbagai tantangan perubahan yang akan datang tersebut. Dalam kehidupan sosial, masyarakat cenderung akan selalu berubah, pendidikan memiliki peran dalam merespon perubahan tersebut. Menurut Undang-undang Sistem Pendidikan Nasional (Sisdiknas) Pasal 1 ayat 1 tahun 2003 Pendidikan adalah usaha sadar dan terencana untuk mewujudkan suasana belajar dan proses pembelajaran agar peserta didik secara aktif mengembangkan potensi dirinya untuk memiliki kekuatan spiritual keagamaan, pengendalian diri, kepribadian, kecerdasan, akhlak mulia, serta keterampilan yang diperlukan dirinya, masyarakat, bangsa dan negara. Untuk mencapai tujuan tersebut, pendidikan dapat dilakukan salahsatunya di jenjang sekolah formal seperti sekolah. Pembelajaran yang dilakukan di sekolah tersusun secara sistematis untuk mencapai tujuan yang diharapkan. Salahsatu indikator tercapainya tujuan pembelajaran adalah prestasi belajar yang diperoleh peserta didik. Prestasi pembelajaran dicapai sebagai bentuk penguasaan peserta didik terhadap materi yang telah diajarkan. Prestasi belajar seseorang sesuai dengan tingkat keberhasilan sesuatu dalam mempelajari materi pelajaran yang dinyatakan dalam bentuk nilai atau raport setiap bidang studi setelah mengalami proses belajar mengajar. Prestasi belajar siswa dapat diketahui setelah diadakan evaluasi. Hasil dari evaluasi dapat memperlihatkan tentang tinggi atau rendahnya prestasi belajar siswa ( Hamdu dan Agustina, 2011:83) Prestasi belajar dipengaruhi oleh banyak faktor baik internal maupun faktor eksternal. Salah satu yang mempengaruhi prestasi belajar adalah motivasi belajar seperti yang di temukan oleh Mawarsih dkk (2013) dan Asriati (2016). Selain motivasi belajar, prestasi belajar juga dipengaruhi oleh fasilitas belajar seperti yang di temukan oleh Priastuti (2016) (Sholeh, 2018).

Pendidikan adalah suatu bentuk investasi jangka panjang yang penting bagi seorang manusia. Pendidikan yang berhasil akan menciptakan manusia yang pantas dan berkelayakan di masyarakat serta tidak menyusahkan orang lain. Masyarakat dari yang paling terbelakang sampai yang paling maju mengakui bahwa pendidikan atau guru merupakan satu diantara sekian banyak unsur pembentuk utama calon anggota utama masyarakat. Pendidkan yang berhasil akan menciptakan manusia yang pantas dan berkelayakan di masyarakat sehingga menjadi penting pendidikan untuk mencetak manusia yang memiliki berkualitas dan berdaya saing.

Pendidikan juga merupakan kegiatan yang dilakukan dengan sengaja agar anak didik memiliki sikap dan kepribadian yang baik, sehingga penerapan pendidikan harus diselenggarakan sesuai dengan sistem pendidikan nasional. Dalam hal ini penentu kualitas pendidikan adalah ketika bagaimana pendidikan itu disampaikan di tingkat sekolah dasar. Karena itulah pada saat pendidikan dasar pengembangan akan potensi siswa harus lebih diperhatikan dan diarahkan dengan baik Sekolah yang merupakan lembaga pendidikan formal, harus mampu mengembangkan seluruh potensi yang dimiliki oleh peserta didik. Sekolah merupakan lembaga yang bersifat kompleks dan unik. Bersifat kompleks karena sekolah sebagai organisasi memiliki berbagai dimensi yang satu sama lainnya saling berkaitan dan saling menunjang. Bersifat unik karena sekolah memiliki karakter tersendiri, dimana didalamnya terdapat proses belajar mengajar, tempat terselenggaranya pembudayaan yang ditunjukkan bagi peningkatan kualitas dan pengambangan potensi peserta didik. Potensi peserta didik tersebut meliputi aspek kognitif, afektif, dan psikomotor. Sekolah sebagai lembaga pendidikan yang dapat mengubah cara berpikir, pola hidup, kebiasaan, dan tata cara pergaulan. Guru merupakan fasilitator dalam pendidikan di sekolah dan dapat meningkatkan siswa dalam prestasi belajar. Selain guru ada faktor yang mempengaruhi proses belajar siswa, yaitu: Faktor Internal dan Faktor Eksternal. Faktor internal biasanya terdiri atas intelegensi, minat, bakat, motivasi, mental dan perhatian, dan faktor eksternal terdiri dari lingkungan sekolah, keluarga, dan masyarakat (Fauziah, 2017). 
Guru dapat diibaratkan sebagai pembimbing perjalanan, yang berdasarkan pengetahuan dan pengalaman bertanggung jawab atas kelancaran perjalanan peserta didik dalam proses pembelajaran. Dalam proses pembelajaran peserta didik tentunya adanya beberapa hal yang mempengaruhi seperti motivasi, kematangan, hubungan peserta didik dengan guru, kemampuan verbal, rasa aman dan keterampilan guru dalam berkomunikasi atau berinteraksi dengan siswa menjadi faktor penting guru dalam proses pembelajaran. Dimana dalam proses belajar pada manusia dapat dirumuskan sebagai suatu aktivitas mental atau psikis yang berlangsung dalam interaksi aktif dengan lingkungan, yang menghasilkan perubahanperubahan dalam pengetahuan dan nilai sikap. Perubahan itu bersifat relatif konstan dan berbekas. Sehingga guru mendai penting dalam proses pembelajaran peserta didik dalam berupaya mewujudkan perubahan sikap dan tingkah laku

Sudarwan (2002:2) motivasi diartikan sebagai kekuatan, dorongan, kebutuhan, semangat, tekanan, atau mekanisme psikologis yang mendorong seseorang atau sekelompok orang untuk mencapai prestasi tertentu sesuai dengan apa yang dikehendakinya. Hakim (2007:26) mengemukakan pengertian motivasi adalah suatu dorongan kehendak yang menyebabkan seseorang melakukan suatu perbuatan untuk mencapai tujuan tertentu. Huitt,W. (2001) mengatakan motivasi adalah suatu kondisi atau status internal (kadang-kadang diartikan sebagai kebutuhan, keinginan, atau hasrat) yang mengarahkan perilaku seseorang untuk aktif bertindak dalam rangka mencapai suatu tujuan. Ditambahkan Gray (Winardi, 2002) mengemukakan bahwa motivasi merupakan sejumlah proses, yang bersifat internal atau eksternal bagi seorang individu, yang menyebabkan timbulnya sikap antusiasme dan persistensi, dalam hal melaksanakan kegiatan- kegiatan tertentu (Suprihatin, 2015).

Tujuan pendidikan dewasa ini akan sulit sekali untuk dikembangkan, sebab pendidikan secara formal memiliki lingkup yang sangat luas. Lingkupan ini mendorong siswa sebagai poin terdidiknya menjadi minim gerak. Akan tetapi pendidikan seharusnya perlu mendapatkan penanganan yang serius. Hal tersebut, secara garis besar pendidikan berupaya membangun kemampuan dan watak. Oleh karena itu kemampuan dan watak menjadi fokus yang seharunya tidak diabaikan. Dalam hal ini motivasi belajar termasuk dalam pendidikan karakter itu sendiri.

Motivasi merupakan salah satu faktor yang turut menentukan keefektifan pembelajaran. Motivasi adalah tenaga pendorong atau penarik yang menyebabkan adanya tingkah laku kearah tujuan tertantu, peserta didik akan belajar sungguh-sungguh apabila memiliki motivasi yang tinggi. Dengan kata lain seseorang peserta didik akan belajar dengan baik apabila ada faktor pendorong (motivasi). Dalam kaitan ini guru dituntut memiliki kemampuan membangkitkan motivasi belajar peserta didik sehingga dapat mencapai tujuan belajar.

Menurut Haryadi (2012: 51), motivasi tidak hanya penting untuk membuat siswa melakukan aktifitas belajar, melainkan juga menentukan seberapa banyak siswa dapat belajar dari aktifitas yang siswa lakukan atau informasi yang dihadapi. Sardiman (2012: 83) menyebutkan ciri-ciri siswa yang memiliki motivasi belajar adalah 1) tekun menghadapi tugas, 2) ulet menghadapi kesulitan belajat, 3) menunjukkan minat terhadap belajar, 4) lebih senang belajar mandiri, 5) cepat bosan pada tugas-tugas yang rutin, dan 6) tidak mudah melepaskan hal yang diyakini itu.

Motivasi belajar adalah "sesuatu yang menggerakkan atau mendorong siswa untuk belajar dan menguasai materi pelajaran yang sedang diikutinya" ( Abdorrakhman, 2007). Sehubungan dengan pentingnya motivasi belajar yang harus dimiliki oleh siswa untuk keberhasilan pendidikan, maka peran guru sangat berpengaruh didalam proses pembelajaran. Banyak metode yang digunakan guru dalam mengajar supaya siswa tidak bosan, tetap antusias dalam belajar, mengerjakan tugas dengan baik, semangat belajar dan aktif dalam belajar. Namun faktanya, tidak sedikit siswa yang membuat guru gelisah dengan adanya siswa kurang semangat, kurang memperhatikan penjelasan guru, bahkan sedikit menggunakan pemikirannya dalam mengerjakan tugas mandiri, dan kurang adanya minat belajar siswa. Berdasarkan hasil observasi pada waktu PPL di SMAN 1 Kediri, terdapat siswa yang berasal dari berbagai daerah, khususnya Jawa dan Papua. Di dalam kelas terdapat perbedaan yang terjadi dalam belajar dari masing-masing siswa baik siswa Jawa maupun Papua.Jika dilihat dari hasil observasi, siswa Jawa lebih antusias dan terlihat lebih aktif.Siswa Papua sendiri 
terkadang harus diberi stimulus terlebih dahulu supaya mereka mau ikut antusias (Arumsari, 2017).

Hasil analisis IKMS yang diberikan oleh siswa kelas VIII di SMP Mardisiswa 2 Semarang bersama guru bimbingan dan konseling (BK) diperoleh informasi bahwa mayoritas siswa mengalami permasalahan pada bidang belajar. Permasalahan itu diantaranya meliputi kesulitan dalam mendapatkan informasi tentang cara belajar efektif dan efisien 57,3\%, informasi tentang cara mempersiapkan diri menghadapai tes/ujian 55,3\%, informasi tentang kesulitan menumbuhkan semangat belajar yang menurun $58,4 \%$.

Pada bidang belajar, biasanya siswa mengalami kesulitan dalam menumbuhkan motivasi belajarnya secara teratur atau signifikan. Pada dasarnya, siswa mengalami kebosanan dalam belajarnya dikarenakan hal tersebut. Motivasi belajar merupakan bagaian teramat penting dalam proses Kegiatan Belajar Mengajar (KBM), diamana anak didik perlu juga melatih dan mengembangkan dirinya agar senantiasa memiliki motivasi belajar yang baik. Sehingga ketika dalam proses belajar dapat semaksimal mungkin menyerap informasi yang diberikan oleh para guru, dan hasilnya prestasi belajarnya juga lebih baik.

Menurut Nuzliah (2015: 59) mengatakan bahwa motivasi belajar merupakan salah satu faktor yang dapat mengatasi problem solving (pemecahan masalah) siswa. Oleh karena itu, motivasi belajar dapat menyebabkan siswa tekun belajar. Sebaliknya jika siswa kurang atau tidak memiliki motivasi untuk belajar, maka siswa tidak akan tahan lama belajar. Hal ini berarti motivasi sangat berpengaruh terhadap ketahanan dan ketekunan dalam belajar.

Dalam membantu siswa untuk meningkatkan motivasi belajar siswa ada beberapa layanan bimbingan dan konseling diantaranya: layanan informasi, bimbingan kelompok, konseling kelompok, konseling individual. Peneliti menggunakan layanan informasi sebagai alternatif untuk meningkatkan motivasi belajar siswa. Layanan informasi adalah layanan bimbingan dan konseling yang memungkinkan peserta didik menerima dan memahami berbagai informasi, seperti layanan informasi pendidikan dan jabatan yang dapat digunakan sebagai bahan pertimbangan dan pengambilan keputusan untuk kepentingan peserta didik. Layanan informasi bertujuan membekali individu dengan berbagai pengetahuan dan pemahaman tentang berbagai hal yang berguna untuk mengenal diri, merencanakan, dan mengembangkan pola kehidupan sebagai pelajar, anggota keluarga dan masyarakat. (Prayitno, 2001: 83).

Salah satu teknik dalam pembelajaran yang dapat diimplementasikan dalam layanan informasi adalah teknik pembelajaran learning cell. Menurut Elizabert E. Barkley, dkk. (2016: 211) menjelasakan bahwa dalam learning cell, siswa membuat sejumlah pertanyaan mengenai tugasatau topik yang diberikan oleh guru kemudian berkerjasama dalam membahas topik tersebut dengan pasangan atau kelompok, secara bergantian bertanya dan menjawab pertanyan satu sama lain.

Berdasarkan latar belakang permasalahan di atas, penulis tertarik ingin mengetahui lebih lanjut dengan melakukan penelitian tentang permasalahan motivasi belajar yang dialami oleh siswa kelas VIIII di SMP Mardisiswa 2 Semarang melalui penelitian yang berjudul "Efektivitas Layanan Informasi dengan Teknik Learning Cell untuk Meningkatkan Motivasi Belajar Siswa Kelas VIII di SMP Mardisiswa 2 Semarang.

\section{Metode}

Menurut Sugiono (2016:14), metode penelitian dapat diartikan sebagai metode penelitian yang berlandaskan pada filsafat positivisme, digunakan untuk meneliti pada populasi atau sampel tertentu, teknik pengambilan sampel pada umumnya dilakukan secara random, pengumpulan data menggunakan instrumen penelitian, analisis data bersifat kuantitatif/statistik dengan tujuan untuk menguji hipotesis yang telah ditetapkan.

Dalam penelitian ini peneliti menggunakan desain penelitian true eksperimental pretestposttest control group design. Menurut Sugiono (2016:112), dalam desain ini peneliti dapat mengontrol semua variabel luar yang mempengaruhi jalannya eksperimen. Sampel yang digunakan untuk eksperimen maupun sebagai kelompok kontrol diambil secara random dari 
populasi tertentu, kemudian diberi pretest untuk mengetahui keadaan awal adakah perbedaan antara kelompok eksperimen dan kelompok kontrol., selanjutnya dapat digambarkan desain penelitian berikut ini :

\begin{tabular}{|lll|}
\hline $\mathrm{O}_{1}$ & $\mathrm{X}$ & $\mathrm{O}_{2}$ \\
& & \\
\hline
\end{tabular}

Gambar 1. Desain Penelitian

Keterangan :

$X$ : Treatment layanan konseling

$\mathrm{O}_{1}$ : Pre-test pada kelas eksperimen

$\mathrm{O}_{2}$ : Post-test pada kelas ekperimen

$\mathrm{O}_{3}$ : Pre-test pada kelas kontrol

$\mathrm{O}_{4}:$ Post-test pada kelas kontrol

\section{Hasil dan Pembahasan}

Tabel 1. Hasil Rata-rata Pre Test dan Post Test

\begin{tabular}{lll}
\hline Kelompok & $\begin{array}{l}\text { Rata-rata } \\
\text { Pre test }\end{array}$ & Post Test \\
\hline Kelompok Kontrol & 47 & 58 \\
Kelompok Eksperimen & 43 & 63,5 \\
\hline
\end{tabular}

Berdasarkan perhitungan Uji-t diperoleh $t_{\text {hitung }}$ sebesar 10,3 sementara $t_{\text {tabel }}$ dengan $\mathrm{db}=$ $(\mathrm{n} 1+\mathrm{n} 2)-2=(30+30)-2=58$ dan taraf signifikan 5\% $(0,05)$ sebesar 2,021 (lihat tabel $\mathrm{t}$ ) karena jumlah $t_{\text {hitung }}>t_{\text {tabel }}$ yakni 10,3 $>2,021$ jadi dapat diartikan lebih besar maka Ha diterima. Dapat disimpulkan bahwa ada pengaruh penggunaan layanan informasi dengan teknik learning cell efektif terhadap motivasi belajar di sekolah.

Kesimpulan akhir dapat dijelaskan bahwa pemberian treatment layanan informasi dengan teknik learning cell dapat digunakan untuk meningkatkan pemahaman siswa dalah menentukan motivasi belajar di sekolahnya dengan terbukti dengan pelaksanaan treatment yang dilakukan dengan selama lima kali pertemuan dengan pemberian treatment. Dilihat dalam perbandingannya dari hasil perhitungan posttest yang diberikan kepada kelompok eksperimen yaitu layanan bimbingan untuk meningkatkan motivasi belajar siswa memiliki rata-rata nilai posttest lebih tinggi daripada rata-rata nilai posttest kelompok kontrol tanpa perlakuan yaitu hasil skornya sebanyak 63,5>58. Maka dapat dikatakan bahwa untuk meningkatkan motivasi belajar siswa lebih efektif di kelompok eksperimen daripada kelompok kontrol tanpa ada sebuah perlakuan.

Sesuai dengan hasil pengujian pada hipotesis pertama dengan membandingkan skor pretest dan posttest dalam menentukan motivasi belajar di sekolah dimana terdapat peningkatan skor motivasi belajar di sekolah setelah diberikan untuk meningkatkan motivasi belajar siswa. Berdasarkan perhitungan analisis data bahwa hasil pretest pada kelompok eksperimen memiliki total skor 706 dengan rata-rata 44,1 sedangkan kontrol memiliki total skor 777 dengan rata-rata 48,6. Sedangkan hasil posttestnya pada kelompok eksperimen memiliki total 966 dengan rata-rata 60,37 sedangkan kelas kontrol memilki total 910 dengan rata-rata 56,9 .

Berdasarkan hasil analisis uji $t$ perbedaan bahwa posttest diantara kelompok eksperimen dengan kelompok kontrol terhadap motivasi belajar di sekolah dengan menggunakan rumus uji $t$ didapatkan sebesar $t_{\text {hitung }}$ sebesar 10,3 sedangkan $t_{\text {tabel }}$ sebesar 2,021 dengan $\mathrm{db}=(\mathrm{n} 1+\mathrm{n} 2)-2$ 
$=(30+30)-2=58$ dan taraf signifikan $5 \%$ maka $t_{\text {hitung }}$ lebih besar dari berarti $t_{\text {tabel }}$ artinya Ho ditolak dan $\mathrm{Ha}$ diterima, sehingga dapat disimpulkan dengan melalui hipotesis yang berbunyi "layanan informasi dengan teknik learning cell efektif untuk motivasi belajar di sekolah pada siswa kelas VIII di SMP Mardisiswa 2 Semarang.

\section{Simpulan dan Saran}

Berdasarkan hasil analisis data bahwa hasil pretest pada kelompok eksperimen memiliki total skor 706 dengan rata-rata 44,1 sedangkan kontrol memiliki total skor 777 dengan rata-rata 48,6 yang dapat diartikan antara kelompok eksperimen dengan kelompok kontrol tidak ada sebuah perbedaan. Sedangkan hasil posttestnya pada kelompok eksperimen memiliki total 966 dengan rata-rata 60,37, disisi lain kelas kontrol memilki total 910 dengan rata-rata 56,87, sehingga dapat diartikan antara kelompok eksperimen dengan kelompok kontrol terjadi perbedaan.

Selain itu, dari hasil analisis uji t bahwa posttest diantara kelompok eksperimen dengan kelompok kontrol didapatkan hasil thitung $=10,3$. Untuk memastikan apakan perbedaan tersebut signifikan maka hasil tersebut dikonsultasikan dengan ttabel...Dengan $\mathrm{db}=(\mathrm{n} 1+\mathrm{n} 2)-2=$ $(30+30)-2=58$ dan taraf signifikan 5\% maka diperoleh ttabel=2,021. Karena thitung $=10,3>$ ttabel= 2,021 maka thitung lebih besar dari ttabel artinya Ho ditolak dan Ha diterima, sehingga dapat disimpulkan bahwa "layanan informasi dengan teknik learning cell untuk meningkatkan motivasi belajar siswa kelas VIII di SMP Mardisiswa 2 Semarang.

\section{Daftar Pustaka}

Ali, dan Asrori. 2004. Belajar \& Pembelajaran. Yogyakarta: Teras.

Arikunto, Suharsimi. 2010. Prosedur Penelitian Suatu Pendekatan Praktik. Jakarta: Rineka Cipta

Aritonang, Keke T. 2008. Minat dan Motivasi dalam Meningkatkan Hasil Belajar Siswa. Jurnal Pendidikan Penabur.

Arumsari, Rindang . 2017. Perbedaan Motivasi Belajar Antara Siswa Yang Berasal Dari Jawa Dan Dari Papua Di Sman 1 Kediri Tahun Ajaran 2016/ 2017 . Jurnal Simki-Pedagogia Vol. 01 No. 01 Tahun 2017

Dimyati. 2007. Pengaruh Motivasi Belajar Siswa Terhadap Prestasi Belajar IPA di Sekolah Dasar. Jurnal Penelitian Pendidikan vol 12, No 1.

Elizabert E. Barkley, dkk. 2016. Colaborative Learning Techinques. Bandung: Nusa Media

Fauziah, Amni. 2017. Hubungan Antara Motivasi Belajar Dengan Minat Belajar Siswa Kelas Iv Sdn Poris Gaga 05 Kota Tangerang . JURNAL JPSD Vol. 4 No. 1 Tahun 2017

Hamalik, Oemar. 2001. Proses Belajar Mengajar. Jakarta: Bumi Aksara.

Hamdu, Ghullam dan Lisa Agustina. 2011. Pengaruh Motivasi Belajar Siswa terhadap Prestasi Belajar IPA di Sekolah Dasar. Jurnal Penelitian Pendidikan Vol. 12 No. 1 Tahun 2011.

Hisyam Zaini, dkk. 2008. Strategi Pembelajaran Aktif. Yogyakarta: Pustaka Insan Mandiri

Nuzliah. 2015. Kontribusi Motivasi Belajar, Kreativitas terhadap Problem Solving (Pemecahan Masalah) Siswa dalam Belajar Serta Implikasi terhadap Bimbingan dan Konseling di SMPN 29 Padang. Jurnal Edukasi Vol 1 No. 2 Tahun 2015. 
Tamayanti, Yoga S. 2017. Pengaruh Pemberian Layanan Bimbingan Teknik Diskusi Kelompok Terhadap Regulasi Diri Siswa Dalam Belajar Di SMP N 1 Semen Tahun Ajaran 20162017. Kediri: Universitas Nusantara PGRI Kediri.

Prayitno. 2004. Layanan Bimbingan dan Konseling Kelompok Dasar dan Profil. Jakarta: Ghalia Indonesia.

Sardiman. A.,M. 2011. Interaksi \& Motivasi Belajar Mengajar. Jakarta: Rajawali Pers.

Sholeh, Badrus . 2018. Pengaruh Motivasi Belajar Dan Fasilitas Belajar Terhadap Prestasi Belajar Ips Siswa Smp Nurul Iman Parung Bogor Tahun Ajaran 2017/2018 . Jurnal Pendidikan, Ekonomi dan Bisnis Vol 3 No 2 Oktober 2018

Sudjana. 2005. Metode Statistika. Bandung: Tarsito

Seri Pemandu BK. 2004. Pelayanan Bimbingan dan Konseling di Sekolah Menengah Kejuruan.

Sugiyono. 2017. Metode Penlitian Kuantitatif, Kualitatif, dan R\&D. Bandung: Alfabeta.

Suprihatin, Siti. 2015. Upaya Guru Dalam Meningkatkan Motivasi Belajar Siswa . Jurnal Pendidikan Ekonomi UM Metro. Vol.3.No.1 (2015)

Uno, Dr. Hamzah B. 2016. Teori Motivasi \& Pengukurannya. Jakarta: Bumi Aksara.

Winkel, W.S \& Sri Hastuti.2005. Bimbingan dan Konseling di Institusi Pendidikan. Jakarta: PT. Grasindo. 